\section{Stability analysis of pure lines and a multiline of soybean in different locations}

\author{
Aline Köhn Carneiro ${ }^{1^{*}}$, Adriano Teodoro Bruzi ${ }^{2}$, José Luiz de \\ Andrade Rezende Pereira ${ }^{3}$ and Everton Vinicius Zambiazzi ${ }^{2}$
}

\begin{abstract}
To compare agronomic performance and phenotypic stability among individual soybean lines and a multiline, eight cultivars and a mixture of them were evaluated in six environments in the 2014/2015 and 2015/2016 crop seasons. At maturity, grain yield $\left(\mathrm{bg} \mathrm{ha}^{-1}\right)$, lodging score, plant height $(\mathrm{cm})$, and first pod height $(\mathrm{cm})$ were evaluated. In the 2015/2016 season, the grain oil and protein content were also evaluated. The GXE interaction was determined by the ecovalence method. The cultivar V-TOP RR had the highest yield, but it was also the highest contributor to the GXE interaction, while the multiline was one of the most stable. The average yield of the multiline did not differ from the average yield of the lines, i.e., the multiline was stable and high yielding. For the other traits, there were no differences between the averages of lines and the multiline by the confidence interval. The mixture of lines is an efficient strategy to increase phenotypic stability in soybean.
\end{abstract}

Keywords: Glycine max (L.) Merrill, genotype mixture, phenotypic stability, genotype-environment interaction.

\section{INTRODUCTION}

Soybean (Glycine max L. Merrill) is an important global crop. Brazil is the second largest soybean producer in the world, and planted area and production has continued to increase over the years (CONAB 2019). Soybeans are cultivated throughout most of Brazil, and has thus been exposed to a wide range of environments and climates, with differences in soil, temperature, rainfall, and photoperiod. The same soybean cultivar produces different yields depending on variations in environmental conditions. This condition is called the genotype $x$ environment interaction ( $\mathrm{GxE}$ ) and it hinders identification of superior and stable cultivars for the same crop season (Branquinho et al. 2014).

According to Ramalho et al. (2012), there are three ways to determine the effect of the genotype $x$ environment interaction. The first way is to identify specific genotypes for each environment. The second way is to perform ecological zoning and subdivide a region into more homogeneous subregions. The third and most used way is identification of cultivars with high phenotypic stability. This strategy consists of identifying genotypes that tend to remain more stable in the face of environmental variations (Becker and Léon 1988, Bruzi et al. 2007, Cruz et al. 2012). In order to evaluate performance in the desired environments and quantify the adaptability and stability of cultivars, it is common and essential to carry out multi-environment trials (Bhartiya et al. 2017).
Crop Breeding and Applied Biotechnology 19(4), 395-401, 2019 Brazilian Society of Plant Breeding. Printed in Brazil http://dx.doi.org/10.1590/198470332019v19n4a56
${ }^{*}$ Corresponding author:
E-mail: alinekohncarneiro@gmail.com
(D) ORCID: 0000-0002-5723-7696

Received: 25 January 2018 Accepted: 01 August 2019

\footnotetext{
${ }^{1}$ Universidade Federal do Rio de Janeiro, Departamento de Bioquímica Médica Leopoldo de Meis, 21.941-590, Rio de Janeiro, RJ, Brazil

${ }^{2}$ Universidade Federal de Lavras, Departamento de Agricultura, Campus Universitário, 37.200-000, Lavras, MG, Brazil ${ }^{3}$ Instituto Federal de Educação Ciência e Tecnologia do Sul de Minas Gerais, 37.576-000, Inconfidentes, MG, Brazil
} 
Phenotypic stability is an important concept for researchers interested in studying the genotype $\mathrm{x}$ environment interaction. "Stability" refers to the relative ability of genotypes to adapt to climatic fluctuations over the course of crop years within a given location (Ramalho et al. 2012). A population's genetic structure may influence phenotypic stability; high heterogeneity and heterozygosity confer more stability to the population than high homogeneity and homozygosity (Beckér and Léon 1988, Acquaah 2016).

The main characteristic sought for in a cultivar in a breeding program is high yield, ideally together with good agronomic characteristics, such as easy management and resistance to major pests. However, these cultivars are often totally or almost completely genetically uniform (Trewavas 2001). For soybean, an autogamous plant, all individuals of a population are genetically identical. This feature facilitates management, but it can become a drawback; it has been reported in the literature that cultivars of self-pollinating plants have less capacity for individual buffering because they exhibit homozygosity in most loci, i.e., they are more susceptible to biotic and abiotic stresses (Acquaah 2016). Thus, the choice of strategies for better adaptation to both the predictable and unpredictable effects of environmental fluctuations requires careful selection of the population's genetic structure (Bruzi et al. 2007). One strategy under research is the use of a multiline, i.e., a mixture of genotypes, which was developed to increase the heterogeneity of self-pollinating cultivars. In theory, a genotype mixture would have higher population homeostasis and therefore be more stable than the pure line, and this is important to minimize losses in the face of possible adversities in the field (Acquaah 2016).

In a study using Arabidopsis thaliana as a model to investigate intraspecific competition between plants at different levels of diversity, the genotypic diversity of Arabidopsis was shown to enhance population tolerance to nutritional stress and to a combination of nutritional and heat stress, showing an increase in yield and yield stability compared to the average of the monoculture. The yield from the mixture was as stable and almost as high as the best-performing monoculture throughout the experiment, sustaining the hypothesis that biodiversity increases phenotypic stability (Creissen et al. 2013).

Schutz and Brim $(1968,1971)$ performed studies on intergenotypic competition in soybean, evaluating the performance and stability of the mixtures. The mixtures tested exceeded or matched the yield of the best component of the mixture. The mixtures were also generally more stable than the pure lines. The authors concluded that the increase in yield was closely associated with the fact that there was no competition loss between plants, whereas the effects of complementary and super compensatory competitions seem to be essential to obtain a high degree of stability in a heterogeneous population. To date, there have been no reports on use of this strategy for soybean in Brazil.

The aim of the present study was to compare agronomic performance among individual soybean lines and the mixture of lines, and to evaluate and compare the phenotypic stability of the genotypes tested.

\section{MATERIAL AND METHODS}

The phenotypic data used in this study were obtained from experiments carried out in six environments (sites and crop season) in the state of Minas Gerais, Brazil, in the 2014/2015 and 2015/2016 crop years. The site characteristics, such as altitude, latitude, and longitude, are shown in Table 1.

Eight commercial cultivars from different origins and a mixture of them were evaluated (Table 2). The cultivars were chosen considering similarity among them as a criterion, because this similarity is a fundamental precept of multiline composition (Ramalho et al. 2012). All cultivars have the same pubescence color and belong to similar relative maturity groups. A priority was that each cultivar has a different reaction in relation to the major diseases that affect soybean cultivation.

Table 1. Site characteristics according to altitude $(\mathrm{m})$, latitude, and longitude variables

\begin{tabular}{|c|c|c|c|}
\hline Location & Altitude (m) & Latitude & Longitude \\
\hline Lavras & 918 & $21^{\circ} 14^{\prime} 43^{\prime \prime} \mathrm{S}$ & 440 59' 59” W \\
\hline Patos de Minas & 832 & $18^{\circ} 34^{\prime} 44^{\prime \prime} \mathrm{S}$ & $46^{\circ} 31^{\prime} 04^{\prime \prime} W$ \\
\hline Itutinga & 969 & $21^{\circ} 17^{\prime} 52^{\prime \prime} \mathrm{S}$ & $44^{\circ} 39^{\prime} 28^{\prime \prime} \mathrm{W}$ \\
\hline Inconfidentes & 869 & $22 \circ 19^{\prime} 01^{\prime \prime} \mathrm{S}$ & $46019^{\prime} 40^{\prime \prime} \mathrm{W}$ \\
\hline
\end{tabular}


Stability analysis of pure lines and a multiline of soybean in different locations

Table 2. List of cultivars evaluated, the companies from which they came, the maturity group (M.G.) they belong to, and their disease resistance

\begin{tabular}{lccc}
\hline Cultivars & Companies & M.G. & Disease Resistance \\
\hline BMXFORÇA RR & Brasmax & 6.2 & stem canker, Phytophthora rot \\
CD 202 RR & Coodetec & 6.4 & stem canker, frog eye \\
CD 215 RR & Coodetec & 5.9 & Phytophthora rot \\
NA 5909 RG & Nidera & 5.9 & stem canker, frog spot, bacterial infection \\
NK 7059 RR & Syngenta & 6.2 & stem canker, bacterial pustule, frog eye, Phytophthora rot, cyst nematodes \\
V - MAX RR & Syngenta & 6.2 & stem canker, frog eye, cyst nematodes \\
V - TOP RR & Syngenta & 5.9 & frog eye, Phytophthora rot \\
\hline
\end{tabular}

A randomized complete block experimental design was used in a $6 \times 9$ factorial scheme, i.e., six environments and nine treatments (eight cultivars and the mixture of them), with three replications. Each plot consisted of two 4-m rows, at a spacing of $0.50 \mathrm{~cm}$ between the rows and external border. Each treatment was composed of a different cultivar, except for the final treatment, which was composed of a mixture of all the cultivars in equal proportion.

The traits evaluated were grain yield in 60-kg bags per hectare (bg ha-1), lodging score (Bernard et al. 1965), plant height $(\mathrm{cm})$, first pod height $(\mathrm{cm})$, and the oil and protein content in the grain $(\%)$. The percent of protein and oil content were determined in the whole grain by near infrared reflectance spectroscopy (NIRS), according to Heil (2010). Duplicate readings were made on grain from every treatment using the Thermo, Antaris II device with an integrating sphere and resolution of $4 \mathrm{~cm}$.

Grain yield $\left(\mathrm{bg} \mathrm{ha}^{-1}\right)$, lodging score, plant height $(\mathrm{cm})$, first pod height $(\mathrm{cm})$, and oil and protein content $(\%)$ were analyzed with R software (R Development Core Team 2012). The adjusted means were compared by the Scott-Knott (1974) test at $5 \%$ probability. Confidence intervals of the difference between two averages were also estimated using the SISVAR statistical program (Ferreira 2011). For the GxE interaction study, the Wricke (1965) ecovalence $\left(\omega_{\mathrm{i}}\right)$ method was adopted. The contribution to the interaction was obtained for all treatments evaluated considering the grain yield trait. Ecovalence $\left(\omega_{i}\right)$ is given as follows: $\omega_{i}=\Sigma_{k=1}^{n}\left(Y_{i k}-Y_{j}-Y_{k}-Y\right)^{2}$, where $Y_{i k}$ is the phenotypic observation of the genotype " $i$ " in the " $k$ " environment; $Y_{i}$ is the phenotypic observation of genotype " $i$ " in all environments; $Y_{.}$is the phenotypic observation of the " $\mathrm{k}$ " environment for all genotypes; and $\mathrm{Y}$ is the overall average. The relative contribution of each genotype to the genotype $x$ environment interaction is estimated as follows: $\omega_{i}(\%)=\frac{\omega_{i}}{\sum \omega_{i}} \times 100$, where $\omega_{i}$ is the ecovalence value of genotype "i".

\section{RESULTS AND DISCUSSION}

In this study, the coefficient of variation (CV) and accuracy were used to measure experimental precision. The CV, according to Pimentel-Gomes (2009), is classified as low (<10\%), medium (10-20\%), high (20-30\%), and very high (>30\%). Accuracy is considered high above $70 \%$, medium from $30 \%$ to $70 \%$, and low below $30 \%$ (Resende and Duarte 2007). The CV ranged from $7.18 \%$ to $34.50 \%$, and accuracy ranged from $81.11 \%$ to $97.55 \%$, i.e. the experimental accuracy was generally good.

To evaluate the agronomic performance of different genotypes, having experiments conducted in several environments is one of the basic objectives of plant breeding programs (Bueno et al. 2006, Acquaah 2016), and one way of evaluating these experiments is by performing a joint analysis among the environments and the crop years (Silva and Duarte 2006, Ward et al. 2019).

For all the traits evaluated, there was a significant difference for the sources of variation for genotypes, for environment, and for the genotype $x$ environment interaction, suggesting that the response of cultivars did not coincide for all the characteristics in the different environments evaluated (Table 3). These differences among the lines tested can be explained because, although the genotypes are similar, there are genetic differences among each of the lines tested, due to their different genetic backgrounds, which, in association with environmental factors like temperature, water availability, and soil conditions, caused differences in phenotypic observations (Silva et al. 2017, Gesteira et al. 2018). 
Table 3. Summary of joint analysis of variance for all traits evaluated, considering the six environments in two crop seasons (2014/2015 and 2015/2016) and summary of the joint analysis of variance for oil and protein contents in the grain for Lavras-MG, ljaci-MG, Itutinga-MG, and Inconfidentes-MG

\begin{tabular}{|c|c|c|c|c|c|c|c|c|}
\hline \multicolumn{6}{|c|}{$2014 / 2015$ and $2015 / 2016$ crop season } & \multirow{2}{*}{\multicolumn{3}{|c|}{$\begin{array}{c}2015 / 2016 \text { crop season } \\
\text { Mean Square }\end{array}$}} \\
\hline \multirow[b]{2}{*}{ Source of variation } & \multirow[b]{2}{*}{ df } & \multicolumn{4}{|c|}{ Mean Square } & & & \\
\hline & & Lodging & Hei & Pod & Yield & df & Oil & Protein \\
\hline Genotypes (G) & 8 & $1.72^{*}$ & $852.00 *$ & $18.50^{*}$ & $244.10^{*}$ & 8 & $2.17^{*}$ & $8.89 *$ \\
\hline Environments (E) & 5 & $10.43^{*}$ & $14,971.00^{*}$ & $722.50^{*}$ & $2,903.90^{*}$ & 3 & $13.29 *$ & $45.19 *$ \\
\hline Replicate & 12 & $2.11^{*}$ & $138.00 *$ & 7.10 & 72.50 & 8 & 0.83 & $2.43^{*}$ \\
\hline $\mathrm{G} \times \mathrm{E}$ & 40 & $1.01^{*}$ & $98.00 *$ & $10.60^{*}$ & $118.00 *$ & 24 & 0.63 & 1.21 \\
\hline CV (\%) & & 34.50 & 7.18 & 15.10 & 21.16 & & 3.89 & 2.62 \\
\hline Accuracy (\%) & & 88.54 & 97.55 & 81.11 & 82.60 & & 82.12 & 94.27 \\
\hline Overall mean & & 1.77 & 89.28 & 16.63 & 41.55 & & 21.63 & 38.03 \\
\hline
\end{tabular}

df: degrees of freedom; Hei: plant height (cm); Pod: first pod height $(\mathrm{cm})$; Yield: bg ha ${ }^{-1} ; \mathrm{F}_{\mathrm{c}}$ : correction factor; $\mathrm{CV}$ : Coefficient of variation. ${ }^{*}$ Significant to $95 \%$ confidence by the $F$ test.

Significant effects of genotypes and environments were fundamental for the significance of the genotype x environment interaction (Bhartiya et al. 2017). The genotype x environment interaction represents the differential phenotypic response of genotypes grown under different environmental conditions that cannot be explained by genotypic or environmental components (Cruz et al. 2012). The results obtained by Silveira et al. (2018), studying the effects of adaptability and stability on grain yield in soybean, corroborate with the results obtained from this study, confirming that there are genotypes adapted to specific environments and possibly genotypes with generalist adaptation, which is the premise of the genotype $x$ environment interaction. Previous studies in the southern region of Minas Gerais, Brazil, also reported the existence of genotype $x$ environment interactions in the soybean crop (Gesteira et al. 2015, Soares et al. 2015, Silva et al. 2016, Silva et al. 2017).

The phenotypic averages of the nine genotypes for all traits evaluated are presented in Table 4. For all of them, a wide variation in the averages is observed. For lodging, the treatments had an average score lower than 2.12 , showing that even in different environments, the plants did not lodge, i.e., the scores can be considered low according to the scale of Bernard et al. (1965), which ranges from 1 to 5 , with 5 being the worst grade for lodging. For grain yield, the BRS 284 cultivar had the lowest performance. V-TOP RR stood out with the highest yield (48.03 bg ha-1); however, this value was not statistically different from the multiline average, which was also high ( $\left.42.28 \mathrm{bg} \mathrm{ha}^{-1}\right)$. For all traits evaluated, the average of the lines did not differ from that of the multiline by the confidence interval (Table 4).

Table 4. Phenotypic means of joint analysis for the traits evaluated in the six environments in two crop seasons (2014/2015 and 2015/2016)

\begin{tabular}{|c|c|c|c|c|}
\hline Genotypes & Lodging & Hei. & Pod & Yield \\
\hline BRS 284 & $2.12 \mathrm{~b}$ & $83.11 \mathrm{c}$ & $14.30 \mathrm{~b}$ & $35.67 \mathrm{~b}$ \\
\hline BMX FORÇA RR & $2.00 \mathrm{~b}$ & $95.07 \mathrm{~b}$ & $17.37 \mathrm{a}$ & $42.53 \mathrm{a}$ \\
\hline CD 202 RR & $2.00 \mathrm{~b}$ & $89.23 \mathrm{~b}$ & $17.51 \mathrm{a}$ & $43.68 \mathrm{a}$ \\
\hline CD 215 RR & $1.61 \mathrm{~b}$ & $85.95 \mathrm{c}$ & $16.82 \mathrm{a}$ & $43.19 \mathrm{a}$ \\
\hline NA 5909 RG & $1.06 \mathrm{a}$ & $75.97 \mathrm{~d}$ & $16.63 \mathrm{a}$ & $36.55 \mathrm{~b}$ \\
\hline NK 7059 RR & $1.83 \mathrm{~b}$ & $89.36 \mathrm{~b}$ & $15.76 \mathrm{~b}$ & $38.74 \mathrm{~b}$ \\
\hline MULTILINE & $1.72 b$ & $91.80 \mathrm{~b}$ & $16.25 \mathrm{a}$ & $42.28 \mathrm{a}$ \\
\hline Pure line means & 1.77 & 88.97 & 16.68 & 41.46 \\
\hline Pure lines vs. multiline & $\begin{array}{c}0.05 \\
(-0.37 \text { to } 0.47)^{1}\end{array}$ & $\begin{array}{c}-2.83 \\
(-7.17 \text { to } 1.51)^{1}\end{array}$ & $\begin{array}{c}0.43 \\
(-1.27 \text { to } 2.13)^{1}\end{array}$ & $\begin{array}{c}-0.82 \\
(-6.79 \text { to } 5.15)\end{array}$ \\
\hline
\end{tabular}

Averages followed by the same letter in the columns belong to the same group by the Scott-Knott test at $95 \%$ reliability. Hei.: plant height ( $\mathrm{cm}$ ); Pod: first pod height (cm); Yield: bg ha-1.

${ }^{1}$ Confidence interval for difference between two means adopting $95 \%$ probability. 
When using a mixture of genotypes, the average of the mixture is expected to equal or exceed the average of the pure lines composing it. In this study, the mean of the multiline did not differ statistically from the average of the pure lines, and this result is in agreement with the result obtained by Döring et al. (2015), who studied the performance and stability of different wheat populations, including pure lines and cultivar mixtures.

The oil and protein varied with both the variation genotype and environment (Table 3). The protein content and oil content in soybean are mainly determined by the genotype of each cultivar but can vary greatly depending on the environment to which the plant is exposed. The average oil content in the bean may range from $15 \%$ to $22 \%$, while the protein content may range from $36 \%$ to $40 \%$ (Arslanoglu et al. 2011). The genotypes that had higher values for protein content, showed statistically lower oil content. These results support the idea that oil and protein contents have a negative association (Gesteira et al. 2018, Jiang et al. 2018, Matei et al. 2018). The oil and protein content is presented in Table 5 . The values obtained in this study corroborate reports in the literature.

There is growing concern regarding the use of genetically uniform cultivars and monoculture as a production system. Although the consumer market most often promotes its use, monoculture restricts the ability of crops to tolerate varied biotic and abiotic stresses. For that reason, the use of cultivar mixtures, such as a multiline, may be an alternative to homogeneity, without loss of yield (Murphy et al. 2013). The use of a multiline is often reported in the literature as a strategy to contain pathogen infections in crops (Mundt 2002), but there are very few studies that quantify the stability of those mixtures.
Table 5. Mean values of oil and protein content in the grain for Lavras-MG, Ijaci-MG, Itutinga-MG, and Inconfidentes-MG in the 2015/2016 crop year

\begin{tabular}{lcc}
\hline Genotype & Oil (\%) & Protein (\%) \\
\hline BRS 284 & $22.46 \mathrm{a}$ & $36.91 \mathrm{c}$ \\
BMX FORÇA RR & $21.31 \mathrm{~b}$ & $39.18 \mathrm{a}$ \\
CD 202 RR & $22.18 \mathrm{a}$ & $36.77 \mathrm{c}$ \\
CD 215 RR & $21.68 \mathrm{~b}$ & $37.68 \mathrm{~b}$ \\
NA 5909 RG & $21.84 \mathrm{a}$ & $37.54 \mathrm{~b}$ \\
NK 7059 RR & $21.17 \mathrm{~b}$ & $38.89 \mathrm{a}$ \\
V - MAX RR & $21.15 \mathrm{~b}$ & $38.06 \mathrm{~b}$ \\
V - TOP RR & $21.40 \mathrm{~b}$ & $39.11 \mathrm{a}$ \\
MULTILINE & $21.51 \mathrm{~b}$ & $38.16 \mathrm{~b}$ \\
\hline Pure line means & 21.65 & 38.02 \\
Pure lines vs. multiline & 0.14 & -0.14 \\
\hline
\end{tabular}

The averages followed by the same letter in the columns belong to the same group by the Scott-Knott test at $95 \%$ reliability.

${ }^{1}$ Confidence interval for difference between two means adopting 95\% probability.

Table 6. Mean values of Wricke Ecovalence $\left(\mathrm{W}_{\mathrm{i}}\right)$ for grain yield

\begin{tabular}{lcc}
\hline Genotype & Mean & Wi (\%) \\
\hline BRS 284 & 35.67 & 14.81 \\
BMX FORÇA RR & 42.53 & 3.44 \\
CD 202 RR & 43.68 & 8.53 \\
CD 215 RR & 43.19 & 10.01 \\
NA 5909 RG & 36.55 & 24.57 \\
NK 7059 RR & 38.74 & 4.26 \\
V - MAX RR & 43.28 & 8.56 \\
V - TOP RR & 48.03 & 21.30 \\
MULTILINE & 42.28 & 4.52 \\
\hline Total & & 100.00 \\
\hline
\end{tabular}

The study of the genotype $x$ environment interaction using accurate statistical tools undoubtedly contributes to greater efficiency of plant breeding programs (Pour-Aboughadareh et al. 2019). One way to study the genotype $x$ environment interaction is to identify cultivars that have greater adaptability and phenotypic stability (Eeuwijk et al. 2016). In this study, the method used to identify cultivars with greater phenotypic stability was the ecovalence method of Wricke (1965). Among the nine genotypes evaluated, NA 5909 RG and V-TOP RR were the cultivars that most contributed to the genotype $x$ environment interaction, with values of $24.57 \%$ and $21.30 \%$, respectively. The genotypes that contributed least to the interaction and therefore had the highest phenotypic stability were BMX FORÇA RR (3.44\%), NK 7059 (4.26\%), and the multiline (4.52\%) (Table 6). The multiline, in addition to being one of the most stable genotypes, showed one of the highest average yields $\left(42.28 \mathrm{bg} \mathrm{ha}^{-1}\right)$. This finding is in accordance with the theory of Allard and Bradshaw (1964) that mixtures of genotypes are more stable because they have greater individual and population homeostasis. Döring et al. (2015) tested performance and stability among composite cross populations, variety mixtures and pure lines of winter wheat and observed that the blends tested were more stable than pure lines, just as observed in the present study. Moreover, this result is in line with the studies of Schutz and Brim (1971) in soybean, Helland and Holland (2001) in oat, and Bruzi et al. (2007) in common bean.

However, the BMX FORÇA RR and NK 7059 RR cultivars were also highly stable, contributing $3.44 \%$ and $4.26 \%$ to the interaction, respectively, and these values are not necessarily associated with the best yield averages. Although they 
are pure lines, according to Becker and Léon (1988), they may be as stable as heterogeneous populations, i.e., these data corroborate the literature. In soybean breeding programs in Brazil, the bulk strategy is adopted for management of segregating populations up to $F_{3} / F_{4}$. During progeny evaluations, the bulk strategy is adopted within families. Under this condition, the cultivars obtained are actually a mixture of lines and not only a single pure line (Tokatlidis 2015). This corroborates the comments of Becker and Léon (1988) and reinforces that cultivars that are as stable as the heterogeneous populations can be identified.

Although plant breeding programs are very fast and efficient in launching higher yielding and adapted cultivars, climate change and pathogen evolution that affect crops and compromise yield are constant setbacks for agriculture. Therefore, the use of intelligent strategies that can help overcome such challenges is extremely important. Our results showed that the use of a multiline in soybean provided an agronomic performance as good as the performance of the best line tested and was still highly stable. From this, we conclude that the use of a multiline is an efficient strategy to increase phenotypic stability in soybean and may be useful in ensuring success of this crop in the field.

\section{REFERENCES}

Acquaah G (2016) Conventional plant breeding principles and techniques. In Al-Khayri JM, Jain SM and Johnson DV (eds) Advances in plant breeding strategies: breeding, biotechnology and molecular tools. Springer, New York, p. 115-158.

Allard RW and Bradshaw AD (1964) Implications of genotypeenvironmental interactions in applied plant breeding. Crop Science 4: 503-508.

Arslanoglu F, Aytac S and Oner EK (2011) Effect of genotype and environment interaction on oil and protein content of soybean (Glycine max (L.) Merrill) seed. African Journal of Biotechnology 10: $18409-18417$.

Becker HC and Léon J (1988) Stability analysis in plant breeding. Plant Breeding 101: 1-23.

Bernard RL, Chamberlain DW and Lawrence RD (1965) Results of the cooperative uniform soybean tests. USDA, Washington, 134p.

Bhartiya A, Aditya JP, Singh K, Pushpendra, Purwar JP and Agarwal A (2017) AMMI \& GGE biplot analysis of multi environment yield trial of soybean in North Western Himalayan state Uttarakhand of India. Legume Research 40: 306-312.

Branquinho RG, Duarte JB, Souza PIM, Neto SPS and Pacheco RM (2014) Environmental stratification and optimization of a multi-environment trial net for soybean genotypes in cerrado. Pesquisa Agropecuária Brasileira 49: 783-795.

Bruzi AT, Ramalho MAP, Abreu AFB, Ferreira DF and Sena MR (2007) Homeostasis of common bean populations with different genetic structures. Crop Breeding and Applied Biotechnology 7: 111-116.

Bueno LCS, Mendes ANG and Carvalho SP (2006) Melhoramento de plantas: princípios e procedimentos. UFLA, Lavras, 319p.

CONAB - Companhia Nacional de Abastecimento (2019) Acompanhamento da safra brasileira de grãos. CONAB, Brasília, 69p.

Creissen HE, Jorgensen TH and Brown JKM (2013) Stabilization of yield in plant genotype mixtures through compensation rather than complementation. Annals of Botany 112: 1439-1447.
Cruz CD, Regazzi AJ and Carneiro PCS (2012) Modelos biométricos aplicados ao melhoramento genético. UFV, Viçosa, 514p.

Döring TF, Annicchiarico P, Clarke A, Haigh Z, Jones HE, Pearce H, Snape J, Zhan J and Wolfe MS (2015) Comparative analysis of performance and stability among composite cross populations, variety mixtures and pure lines of winter wheat in organic and conventional cropping systems. Field Crops Research 183: 235-245.

Eeuwijk FAV, Bustos-Korts DV and Malosetti M (2016) What should students in plant breeding know about the statistical aspects of genotype $\times$ environment interactions? Crop Science 56: 2119-2140.

Ferreira DF (2011) Sisvar: a computer statistical analysis system. Ciência e Agrotecnologia 35: 1039-1042.

Gesteira GS, Bruzi AT, Zito RK, Fronza V and Arantes NE (2018) Selection of early soybean inbred lines using multiple indices. Crop Science 58: 2494-2502.

Gesteira GS, Zambiazzi EV, Bruzi AT, Soares IO, Rezende PM and Silva KB (2015) Seleção fenotípica de cultivares de soja precoce para a região Sul de Minas Gerais. Revista Agrogeoambiental 7: 79-88.

Heil C (2010) Rapid, multi-component analysis of soybeans by FT-NIR Spectroscopy. Thermo Fisher Scientific, Madison, 3p. (Application Note, 51954).

Helland SJ and Holland JB (2001) Blend response and stability and cultivar blending ability in oat. Crop Science 41: 1689-1696.

Jiang GL, Chen P, Zhang J, Florez-Palacios L, Zeng A, Wang X, Bowen RA, Miler A and Berry H (2018) Genetic analysis of sugar composition and its relationship with protein, oil, and fiber in soybean. Crop Science 58: 2413-2421.

Matei G, Meneguzzi C, Woyann LG, Todeschini MH, Trevizan DM, Conte J, Bozi AH and Benin G (2018) Oil, protein and fatty acid profiles of Brazilian soybean cultivars in multi-environmental trials. Australian Journal of Crop Science 12: 686-698.

Mundt CC (2002) Use of multiline cultivars and cultivar mixtures for disease management. Annual Review of Phytopathology 40: 381410.

Murphy KM, Carter AH and Jones SS (2013) Evolutionary breeding and 
Stability analysis of pure lines and a multiline of soybean in different locations

climate change. In Kole C (ed) Genomics and breeding for climateresilient crops: concepts and strategies. Springer Berlin/Heidelberg, p. 377-389.

Pimentel-Gomes F (2009) Curso de estatística experimental. FEALQ, Piracicaba, 451p.

Pour-Aboughadareh A, Yousefian M, Moradkhani H, Poczai P and Siddique KHM (2019) STABILITYSOFT: A new online program to calculate parametric and non-parametric stability statistics for crop traits. Applications in Plant Sciences 7: e1211.

R Development Core Team (2012) R: a language and environment for statistical computing. R Foundation for Statistical Computing, Software, Vienna.

Ramalho MA, Abreu AFB, Santos JB and Nunes JAR (2012) Aplicações da genética quantitativa no melhoramento de plantas autógamas. UFLA, Lavras, 365p.

Resende MDV and Duarte JB (2007) Precisão e controle de qualidade em experimentos de avaliação de cultivares. Pesquisa Agropecuária Tropical 37: 182-194.

Schutz WM and Brim CA (1968) Inter-genotypic competition in soybeans II. Predicted and observed performance of multiline mixtures. Crop Science 8: 735-739.

Schutz WM and Brim CA (1971) Inter-genotypic competition in soybeans III. An evaluation of stability in multiline mixtures. Crop Science 11: 684-689.

Scott A and Knott M (1974) Cluster-analysis method for grouping means in analysis of variance. Biometrics 30: 507-512.
Silva KB, Bruzi AT, Zambiazzi EV, Soares IO, Pereira JLAR and Carvalho MLM (2017) Adaptability and stability of soybean cultivars for grain yield and seed quality. Genetics and Molecular Research 16: 1-15.

Silva KB, Bruzi AT, Zuffo AM, Zambiazzi EV, Soares IO, Rezende PM de, Fronza V, Vilela GDL, Botelho FBS, Teixeira CM and Coelho MAO (2016) Adaptability and phenotypic stability of soybean cultivars for grain yield and oil content. Genetics and Molecular Research 15: 1-11.

Silva WCJ and Duarte JB (2006) Métodos estatísticos para estudo de adaptabilidade e estabilidade fenotípica em soja. Pesquisa Agropecuária Brasileira 41: 23-30.

Silveira DA, Bahry CA, Pricinotto LF, Nardino M, Carvalho IR and Souza VQ (2018) Adaptability and stability of grain yield in soybean. Australian Journal of Crop Science 12: 717-725.

Soares IO, Rezende PM, Bruzi AT, Zambiazzi EV, Zuffo AM, Silva KB and Gwinner R (2015) Adaptability of soybean cultivars in different crop years. Genetics and Molecular Research 14: 8995-9003.

Tokatlidis IS (2015) Conservation breeding of elite cultivars. Crop Science 55: 2417-2434.

Trewavas A (2001) Urban myths of organic farming. Nature 410: 409-410.

Ward BP, Brown-Guedira G, Tyagi P, Kolb FL, Van Sanford DA, Sneller CH and Griffey CA (2019) Multienvironment and multitrait genomic selection models in unbalanced early-generation wheat yield trials. Crop Science 59: 491-507.

Wricke G (1965) Zur Berechning der Okovalenz bei Sommerweizen undhafer. Zeitschrift für Pflanzenzuchtung 52: 127-138. 